Eryk Kotkowicz

(Muzeum Rolnictwa im. ks. Krzysztofa Kluka w Ciechanowcu)

\section{Konferencja „Chłopi na ziemiach dawnej Rzeczypospolitej do czasów uwlaszczenia", Ciechanowiec, 6-7 czerwca 2019 r.}

W dniach 6-7 czerwca 2019 r. w Muzeum Rolnictwa im. ks. Krzyszcja historyczna pt. „Chłopi na ziemiach dawnej Rzeczypospolite do czasów uwłaszczenia” pod kierunkiem naukowym prof. Doroty Michaluk. Organizatorami byli: Muzeum Rolnictwa im. ks. Krzysztofa Kluka w Ciechanowcu, Departament Kultury i Dziedzictwa Narodowego Urzędu Marszałkowskiego Województwa Podlaskiego w Białymstoku, Uniwersytet Mikołaja Kopernika w Toruniu, Zarząd Główny Polskiego Towarzystwa Historycznego w Warszawie, Archiwum Główne Akt Dawnych w Warszawie, Liteuvos Istorijos Institutas w Wilnie.

Konferencja odbyła się w ramach programu badawczego zainicjowanego przez podlaskie władze samorządowe w 2013 r. Głównym celem projektu było podjęcie pogłębionych studiów na temat dziejów województwa, terenów wchodzących w skład Wielkiego Księstwa Litewskiego i szerzej Europu Środkowo-Wschodniej.

Tegoroczna konferencja swą tematyką nawiązywała do sympozjum pt. „Wolni i uwłaszczeni. Chłopi a przemiany społeczne, gospodarcze i polityczne w Europie Wschodniej w XIX i na początku XX wieku" z 8-9 czerwca 2017 r. Tym razem historycy z wielu ośrodków badawczych Polski, Białorusi, Ukrainy, Litwy i Łotwy podjęli się omówienia zagadnień doty- 
czących stanu włościańskiego z wcześniejszego okresu. Badacze zwrócili uwagę na zróżnicowane położenie chłopstwa w folwarkach szlacheckich, królewszczyznach i dobrach biskupich, wzajemne stosunki z mieszczanami, sytuację prawną oraz religijną. Łącznie na konferencji wygłoszono 21 referatów zgrupowanych w czterech panelach tematycznych. Program obrad z 6 czerwca podzielono na dwa bloki.

Pierwszym referentem był prof. Krzysztof Mikulski reprezentujący Uniwersytet Mikołaja Kopernika w Toruniu, który wygłosił referat pt. „Folwark szlachecki i gospodarstwo chłopskie w XVI w.”. Autor starał się wykazać wzajemne zależności gospodarcze występujące między oboma stanami. W pierwszej kolejności skupił się na omówieniu pojęcia pańszczyzny rozumianej jako rodzaj renty nieświadczonej w pieniądzu i jej rynkowej genezie. Profesor Mikulski twierdził, że przyjęcie gospodarki pańszczyźnianej wynikało z samej organizacji włości najpierw biskupiej, później również świeckiej produkującej na potrzeby lokalnego rynku. W dalszej części wypowiedzi scharakteryzował gospodarstwa chłopskie i folwarki pod względem rodzaju produkcji, zajmowanego areału oraz rynku zbytu. Wskazał przy tym na milowe kroki w ustawodawstwie zmierzające do ujednolicenia pańszczyzny i wprowadzenia jej w wymiarze tygodniowym, a nie jak dotąd rocznym (uwzględniając przy tym sytuację wsi zwolnionych z tego obowiązku). Jeśli zaś chodzi o inicjatorów zamiany czynszów na rentę odrobkową wskazywał na stosunkowo wysoki odsetek chłopów, którzy sami występowali z tą inicjatywą w sytuacji niedostatku pieniądza. Autor wskazał również na II połowę XVI w. jako na okres dobrej koniunktury na zborze powodujący rozwój folwarków szlacheckich i zmniejszenie areału pul chłopskich.

Jako drugi głos zabrał dr Michał Sierba z Białoruskiego Towarzystwa Historycznego. W referacie „Powinności kmieci ciągłych we wsiach podlaskich - przykład starostwa tykocińskiego" poruszył zagadnienia świadczeń ponoszonych przez chłopów z okolic Tykocina. Zakres chronologiczny wystąpienia obejmował lata 1559-1616, co zostało wymuszone przez podstawę źródłową, którą stanowiły pomiara włóczna z 1559 r., inwentarze, lustracje z 1616 r. i inne źródła skarbowe. Grupą ludności, która została poddana analizie, byli chłopi służebni obciążeni konkretnymi powinnościami na rzecz starosty, państwa, arendarzy, kościoła czy wewnętrznego samorządu. Wysokość czynszu była uzależniona od jakości gruntów i - jak ustalił autor wystąpienia - większość z nich była sklasyfikowana jako średniej jakości. Doktor Sierba przedstawił wysokości poszczególnych świad- 
czeń uiszczanych przez kmieci w pieniądzu, np. stację, niewodowe, jak i w naturze opłacane od włóki w zbożu, sianie, jajach czy też żywym inwentarzu, które również mogły być płacone w monetach. Zauważył także, że w omawianym okresie zwiększył się wymiar pańszczyzny mieszkańców wsi służebnych z dwóch do trzech dni w tygodniu oraz innych świadczeń obejmujących: tłokę, gwałty, podwody, strużę na zamku tykocińskim, wgruby konne lub piesze.

Kolejnym prelegentem był prof. Witalij Michałowski z Kijowskiego Uniwersytetu im. Borysa Grinczenki, który wygłosił referat pt. „Bojarzy szlachta jako chłopi i ich poddani w świetle inwentarza starostwa barskiego na początku XVII w.”. W owym wystąpieniu autor odbiegł od głównego wątku poruszanego na konferencji i przedstawił warunki egzystencji nizin stanu szlacheckiego na Podolu, głównie w starostwie barskim. Według inwentarza z 1613 r. w omawianej jednostce administracyjno-sądowej istniało 20 wsi bojarskich zamieszkałych przez 143 chłopów, 162 zagrodników i 488 bojarów. Jak podawał autor wystąpienia, większość członków tej ostatniej grupy własnymi rękami obrabiała swą ziemię przy pomocy nielicznej czeladzi. Bojarzy, o których mowa powyżej, oprócz obciążeń na rzecz starostwa barskiego mieli także obowiązki militarne wobec starosty kamienieckiego. Kończąc swój referat, prof. Michałowski postawił pytanie dotyczące klasyfikacji stanowej ludności żyjącej na pograniczu: kto był tam chłopem, a kto szlachcicem?

Doktor Aleksander Dounar z Narodowej Akademii Nauk Białorusi omówił „Położenie społeczne bojarów putnych i pancernych województwa połockiego w Wielkim Księstwie Litewskim w świetle źródeł z połowy XVIII w.”. W pierwszych słowach zwrócił uwagę na występujące w historiografii zainteresowanie wieloma kategoriami ludności chłopskiej i o wiele mniejsze, jeśli idzie o dwie wymienione w tytule grupy społeczne. Nie oznacza to jednak, że temat był całkowicie pomijany. Autor przypomniał słuchaczom badania Michała Bez-Korniłowicza, Władimira Wieszniakowa, Aleksandra Siemiantowskiego i wielu innych, ale zwracał uwagę na brak pogłębionych badań kwestii bojarskiej w XVI-XVIII w. Doktor Dounar skupił się na omówieniu sytuacji tej grupy na podstawie ksiąg sądów grodzkich województwa połockiego i magistratu połockiego. Przedstawił genezę stanu oraz wyszczególnił różnicę między bojarami putnymi i pancernymi a pozostałymi kategoriami ludności chłopskiej, poczynając od XVI w. Posiadali wolność osobistą, prawo własności ziemi w granicach ekonomii połockiej, jej sprzedaży lub zastawu, obowiązek służby wojsko- 
wej, mimo to w żadnym z przytaczanych przez autora dokumentów nie byli oni określani jako szlachta. Dalej omówił organizację wójtostw bojarskich zlokalizowanych przy granicy z Cesarstwem Rosyjskim oraz uprawnienia sądowe wójtostw bojarskich.

Jako kolejny wystąpił dr Andrzej Buczyło reprezentujący Instytut Historii im. Tadeusza Manteuffla PAN z referatem pt. „Chłopi we wsiach królewskich guberni łomaskiej w świetle inwentarza z 1789 r.”. Tytułowa gubernia została utworzona w II połowie lat 60 . XVIII w. w wyniku reform Antoniego Tyzenhausa zmierzających do nowej organizacji ekonomii. Autor zwrócił uwagę na źródło użyte do przygotowania referatu, które nie było do tej pory wykorzystywane. Inwentarz guberni łomaskiej z $1789 \mathrm{r}$. jest przechowywany w Litewskim Państwowym Archiwum Historycznym w Wilnie, Fondzie 11 (Komisja Skarbowa Wielkiego Księstwa Litewskiego), pod sygnaturą 1469, i jest kompletny. Zawiera on wykaz włók z podziałem na czynszowe, osiadłe, zwolnione z powinności, należące do arendy, opisy poszczególnych rodzin, wyliczenie gospodarzy i listę powinności wraz z ich wymiarem. Na ich podstawie autor przedstawił strukturę społeczną ludności zamieszkującej omawiany teren, wyszczególniając wsie tatarskie, bojarskie, szlachty czynszowej i chłopskie. Doktor Buczyło omówił różnicę w powinnościach gospodarczych i pozycję społeczną poszczególnych rodzajów ludności. Wyszczególnił również wsie, w których występowały nadania dożywotnie lub dziedziczne dla osób prywatnych. Następnie przeszedł do omówienia poszczególnych powinności, wskazując przy tym na brak korelacji między jakością gruntu, liczbą osób w rodzinie a wysokością świadczeń.

Referat dr. hab. Wiesława Nowosada z Uniwersytetu Mikołaja Kopernika w Toruniu pt. „Chłopi w dobrach biskupów chełmińskich w XVIII w. w świetle inwentarzy" dotyczył kondycji materialnej włościan. Tytułowe inwentarze to spisy dóbr poszczególnych gospodarstw, a wartość rzeczy wyrażano w nich w złotych, złotych pruskich lub florenach. Ten materiał źródłowy jest przechowywany w Archiwum Państwowym w Toruniu w zespole Sąd Dominialny Dóbr Biskupstwa Chełmińskiego. Inwentarze zostały sporządzone na potrzeby wyznaczania działów spadkowych po śmierci poszczególnych chłopów. Autor poddał analizie 41 inwentarzy z lat 1757-1763. Badany okres był na tyle zawężony, że można porównać majątek poszczególnych osób. Jeden z inwentarzy był szlachecki, dwa mieszczańskie, a pozostałe różnych członków społeczności chłopskiej (od sołtysów aż po wyrobników). Autor poddał analizie wyszczególnione w spisach majątko- 
wych dobra ruchome i nieruchome (bez ziemi, która należała do biskupów chełmińskich) oraz ciążące na nich długi lub wierzytelności, które spadkobiercy mogli odzyskać od innych. Doktor hab. Nowosad zwrócił uwagę na znajdujące się w posiadaniu chłopów przedmioty niekojarzące się z ich stanem, np. broń, srebra, żupan i wysokie wydatki pogrzebowe, wskazując, że wielokrotnie chłopi byli zamożniejsi od szlachty wasalnej czy mieszczan zamieszkujących te same dobra.

Jako kolejna wystąpiła dr Neringa Dabrauskaitè z Uniwersytetu Wileńskiego. W referacie pt. „Życie chłopów w majątkach szlacheckich w Wielkim Księstwie Litewskim w XVI i w I połowie XVII w.” zaprezentowała wyniki swych badań nad egzystencją tytułowej grupy społecznej. Dotyczył on głównie realiów codziennego życia włościan, czyli tematu, który był pomijany w dotychczasowej historiografii litewskiej. Jako baza źródłowa do referatu posłużyły relacje podróżników, inwentarze oraz akta procesowe z napadów na chłopów, zawierające opisy utraconego przez nich mienia. Dzięki nim badaczka starała się odtworzyć materialne warunki egzystencji włościan w majątkach szlacheckich. W toku swojej wypowiedzi omówiła zagrodę chłopską, wymieniając wchodzące w jej skład zabudowania, oraz inwentarz żywy. Dużo uwagi poświęciła problemowi chat, charakteryzując ich poszczególne typy i wyposażenie. Następnie przedstawiła bardzo zróżnicowany status majątkowy chłopów litewskich, skupiając się na posiadanej przez nich gotowiźnie, płodach rolnych, środkach transportu, ubraniach i innych ruchomościach.

Trzeci panel tematyczny, prowadzony przez prof. Cezarego Kuklę, rozpoczął prof. Janusz Łosowski z Uniwersytetu Marii Curie-Skłodowskiej $z$ referatem „Chłopi a małe miasta na przykładzie województwa lubelskiego w XVI-XVIII w. Zarys problematyki”. Wystąpienie było poświęcone wzajemnym relacjom między mieszczanami a społecznością wiejską. Autor, odwołując się do wcześniejszej literatury, wskazał powiązania obu stanów w różnych sferach życia, zarówno natury osobistej, jak i ekonomicznej, np. wpisy transakcji chłopskich do ksiąg miejskich, wybór mieszczan na rodziców chrzestnych dla dzieci urodzonych w okolicznych wsiach. Profesor Łosowski poruszył problem nabywania gruntów miejskich przez chłopów na zasadach kupna i darowizny. W ośmiu przebadanych miastach odnotował ponad 200 takich przypadków. W referacie poruszono również kwestie pożyczek, w których przedstawiciele obu stanów występowali i jako pożyczkobiorcy, i jako wierzyciele. Innym poruszanym przez autora zagadnieniem było uczestnictwo chłopów w procesach przed sądami miej- 
skimi. Włościanie występowali w nich jako sprawcy oraz ofiary w sprawach o zabójstwa, kradzieże, niespłacone długi. Między przedstawicielami chłopstwa i mieszczaństwa dochodziło również do małżeństw, co powodowało wzajemne relacje spadkowe. Innym podanym przez autora dowodem na utrzymywanie bliskich kontaktów między stanami miało być zapraszanie chłopów na biesiady i noclegi w domach mieszczańskich. Na uwagę zasługiwała również opieka nad osieroconymi dziećmi pochodzącymi $\mathrm{z}$ innego stanu lub oddanie syna do terminu.

Kolejny prelegent, Jarosław Zawadzki z Archiwum Głównego Akt Dawnych, wygłosił referat pt. „Czy na litewskiej wsi wczesnonowożytnej (do połowy XVII w.) istniało zjawisko względnego przeludnienia?”. Zakres terytorialny tematyki referatu został zamknięty w granicach majątku Iwie w powiecie oszmiańskim, dla którego zachowała się dość duża liczba źródeł, rozszerzony o kilka inwentarzy z innych terenów Wielkiego Księstwa Litewskiego. Autor stwierdził, że przeludnienie wsi litewskiej od II dekady XVII w. do połowy stulecia miało negatywne skutki gospodarcze. Dobra Iwie, według rejestru pomiary włócznej z 1561 r., składały się z miasta i pięciu wójtostw, co stanowiło ok. 380 włók, w tym 28 dworskich. W późniejszym okresie dokupiono jeszcze jedno wójtostwo, uzyskując powierzchnię ok. 500 włók. Stopniowo następowało rozdrobnienie gruntów chłopskich przy wzroście areału dworskiego. Jak zauważył autor, do 1598 r. gospodarstwa chłopskie były dość zamożne i rozległe, jednak sytuacja ta zaczęła się zmieniać w I ćwierci XVII w. Sukcesywnie zwiększano obciążenia pańszczyźniane i czynsz, a co ważniejsze, gospodarstwa chłopskie uległy rozdrobnieniu pod wpływem znacznego wzrostu demograficznego. Ostatecznie w ciągu 30 lat ich liczba uległa podwojeniu, a z czasem ten proces postępował. Jarosław Zawadzki wykazał, że przyczyniło się to do powstawania gospodarstw karłowatych, które niejednokrotnie pustoszały i pozostawały niezagospodarowane, a sami chłopi znacznie ubożeli. To natomiast wpływało na zmniejszenie się liczby rzemieślników pracujących na rzecz włościan, gdyż ci powoli wycofywali się z udziału w lokalnym obrocie gospodarczym, przy jednoczesnym zwiększeniu się liczby warsztatów produkujących na potrzeby dworu.

W pierwszym dniu konferencji ostatnie wystąpienie przypadło w udziale pracownikom Uniwersytetu w Białymstoku - dr. Piotrowi Guzowskiemu i dr. Radosławowi Poniatowi. Referenci postawili bardzo ciekawe pytanie badawcze: czy istniał jeden system pańszczyźniany w dawnej Rzeczypospolitej? Jak zauważyli, trudno mówić o jednym systemie pańszczyźnia- 
nym na terenach państwa polsko-litewskiego. W zależności od regionu różnej wielkości były grunty folwarczne i gospodarstwa chłopskie. Inaczej też wyglądała sytuacja prawna poszczególnych dóbr prywatnych, biskupich, królewskich. Zawierane przez chłopów kontrakty z właścicielami dóbr również nie były takie same. Jak wykazali obaj badacze, trudno jest ustalić jedną definicję poddaństwa, jak również termin dla modelu gospodarki występującego w XVI-wiecznej Rzeczypospolitej, a szerzej w Europie Środkowej i Wschodniej. Omówili termin serfdom, używany w literaturze anglosaskiej i odnoszący się do poddaństwa, pańszczyzny, dominacji folwarków w systemie gospodarczym, słabości wspólnot chłopskich oraz wsparcia państwa, dla określonego modelu gospodarczego. Prelegenci podkreślili przy tym jego użyteczność do badań przedrozbiorowej Rzeczypospolitej, postulując potrzebę wypracowania kwantytatywnego narzędzia, nazwanego przez nich wskaźnikiem lub indeksem stopnia serfdom. Miałby on służyć ustaleniu: sposobu organizacji wspólnoty wiejskiej, kontroli właściciela dóbr nad chłopskim rynkiem ziemi, udziału włościan w rynku, wpływu właściciela na organizację pracy, tego, czy istniał i jak funkcjonował chłopski rynek pracy, czy istniały jakieś prawne ograniczenia systemu folwarczno-pańszczyźnianego. Zdaniem autorów wyliczenia mogą posłużyć do zbadania wpływu serfdom na nierówności ekonomiczne, PKB, możliwości finansowe państwa, standard życia itd.

W drugim dniu konferencji jako pierwsza wystąpiła prof. Lidia Korczak z Uniwersytetu Jagiellońskiego z referatem pt. „Chłopi przed sądem ziemskim i grodzkim w średniowieczu”. Prelegentka rozpoczęła od podkreślenia wagi ksiąg sądowych jako źródeł do badań XIV i XV w. Stanowią one świadectwo kondycji ówczesnego społeczeństwa, w tym kmieci. Autorka zaznaczyła, że dużo cenniejsze są księgi królewskich sądów grodzkich niż ich wiejski odpowiednik, który był sporządzany rzadziej i nie zapisywano w nim wszystkich spaw. $\mathrm{W}$ omawianym okresie kmiecie mieli równy z innymi stanami dostęp do publicznego wymiaru sprawiedliwości. Często występowali jako strona w sprawach sądowych karnych i cywilnych. Autorka omówiła wszystkie z nich na wybranych przykładach.

Jako kolejny głos zabrał prof. Tomasz Wiślicz z Instytutu Historii im. Tadeusza Manteuffla PAN. W referacie pt. „Rebelie chłopskie na ziemiach polskich od statutu toruńskiego do rabacji galicyjskiej - podstawowe zagadnienia badawcze i interpretacje" omówił kwestię oporu włościan w przedrozbiorowej Rzeczypospolitej. Przechodząc do tematu, zwrócił uwagę na możliwość wykorzystania do dzisiejszych badań nad chłopstwem dorobku 
historiografii marksistowskiej, a szczególnie wyników tzw. kwerendy wiejskiej. Alarmował jednocześnie, że bezkrytyczne korzystanie prac autorów wywodzących się z tego nurtu, często tworzących na potrzeby władz komunistycznych w latach 50. i 60. XX w., niesie ze sobą wiele zagrożeń. Zdaniem prof. Wiślicza, jest to prosta droga do przekłamań, porównywalnych z dzisiejszym fenomenem turbolechickich fantazji. Mogą być za to wykorzystywane jako swoiste przewodniki archiwalne. Autor referatu zaznaczył, że dziedzictwo marksistowskie stanowi duży problem interpretacyjny rebelii chłopskich. Dlatego też jako konieczne postulował określenie definicji rebelii chłopskiej w warunkach polskich, ale na podstawie terminologii międzynarodowej; ustalenie miejsca włościańskiego oporu w systemie politycznym Rzeczypospolitej; zbadanie kwestii programów społecznych towarzyszących buntom; reinterpretowanie przyczyn ekonomicznych; określenie roli przywództwa buntów; analizowanie wspólnotowego charakteru rebelii; badanie pamięci o włościańskim oporze z wykorzystaniem etnograficznych i antropologicznych narzędzi badawczych; wypracowanie teoretycznego ujęcia problemu; zbadanie roli religii w buntach.

Doktor Anastazja Skiepjan z Narodowej Akademii Nauk Białorusi omówiła „Religijność chłopów na ziemiach białoruskich Wielkiego Księstwa Litewskiego w XVI-XVIII w. w świetle źródeł pisanych”. Baza źródłowa do tego tematu jest dość ograniczona. Przygotowując wystąpienie, autorka wykorzystała relacje podróżników, akta spraw sądowych, nieliczne wpisy z ksiąg sądów duchownych, statuty właścicieli majątków, inwentarze świeckie i duchowne oraz akty wizytacji. Z uwagi na obszerność podejmowanej problematyki autorka skupiła się jedynie na zachowanych w źródłach przejawach wiary w Chrystusa i siły nadprzyrodzone, członkostwie w bractwach cerkiewnych oraz finansowaniu świątyń. Wykazała, że w XVI i XVII w. chłopi, w odróżnieniu od mieszczan, nie fundowali ośrodków religijnych, ponieważ nie posiadali prawa własności ziemi, a jednocześnie badaczka przedstawiła przypadki inicjowania przez nich akcji fundacyjnej u właścicieli majątków. Sporadycznie włościanie odbudowywali zniszczone miejsca kultu lub je remontowali. Autorka wskazała, że o wiele częściej chłopi uczestniczyli w finansowaniu świątyni, np. spełniając wymogi fundacji jej założyciela, płacąc za śluby, chrzciny, pogrzeby i spowiedź lub składając dobrowolne ofiary. Doktor Skiepjan, omawiając zespołowe formy religijności, skupiła się na bractwach działających przy świątyniach, takich jak miodowe dostarczające wosk na świece i zapewniające poczęstunek z okazji świąt. W dalszej części wypowiedzi przedstawiła obecny 
na wsi białoruskiej problem z uczestnictwem w życiu religijnym parafii i kultywowaniem niechrześcijańskich tradycji. Wymieniła także kary grożące za niedopełnienie spowiedzi wielkanocnej, pracę w dzień święty czy unikanie mszy.

Doktor Jolita Saracevičienè, reprezentująca Instytut Historii Litwy, wygłosiła referat pt. „Kilka zagadnień o religijności chłopów w Wielkim Księstwie Litewskim na podstawie piśmiennictwa XVIII w.". Na początku odniosła się do częstego w historiografii litewskiej zjawiska retrogresywnego przenoszenia utrwalonych w XIX i XX w. form religijności chłopskiej do opisu realiów XVIII-wiecznych. Problem ten wynika z niewielkiej liczby źródeł. Materiał archiwalny wykorzystany przez autorkę to głównie katechizmy, zbiory kazań, przewodniki dla spowiedników, a także wiele świeckich tekstów publicystycznych. Powyższe źródła pozwoliły przyjrzeć się prowadzonej przez Kościół katolicki katechizacji dzieci i dorosłych, roli, jaką w tym procesie odgrywali gospodarze i właściciele ziemscy, oraz wzajemnym relacjom parafian z kapłanami. Doktor Saracevičienė omówiła zalecaną przez duchowieństwo domową naukę podstaw religii oraz płynące stąd zagrożenia dla czystości wiary, wynikające z niedostatecznego poziomu wiedzy rodziców i gospodarzy troszczących się o religijne wychowanie nie tylko członków swych rodzin, ale również najemników. Autorka zwróciła również uwagę na kary grożące za niedopełnianie obowiązków religijnych, bardzo podobne to tych omówionych przez poprzednią prelegentkę. W dalszej części referatu omówiła rolę mszy, a szczególnie kazań i następujących po nich modlitw, w pogłębianiu religijności parafian. Przytoczyła też skierowane do kapłanów wskazówki, które dotyczyły sposobu katechizowania prostego ludu w czasie mszy i spowiedzi. Autorka wykazała również, że częstym problemem w katechizacji wsi litewskiej było niedostateczne wykształcenie duchownych lub złe traktowanie przez nich włościan albo za wysokie opłaty za sakramenty i inne świadczone usługi. W referacie nie zabrakło również odniesień do zabobonów i praktyk pogańskich lub magicznych, kultywowanych oraz łączonych często z kultem świętych przez mieszkańców wsi.

Ostatni panel, prowadzony przez prof. Andrzeja Zakrzewskiego, rozpoczął prof. Krzysztof Ślusarek z Uniwersytecie Jagiellońskiego, który przedstawił problem: „Zmiany granic państwowych na przełomie XVIII i XIX w. a społeczno-prawne położenie chłopów (na przykładzie województw krakowskiego i sandomierskiego)". Omawiany okres - od 1772 r. do końca epoki napoleońskiej - charakteryzował się dużą dynamiką zmian granic 
państwowych i prawnych, wpływających na życie społeczności wiejskiej w Małopolsce Zachodniej. Profesor Ślusarek skupił się na kilku czynnikach, a mianowicie: na wolności osobistej, czyli odejściu od poddaństwa, zmniejszeniu wymiaru pańszczyzny, nieusuwalności z ziemi lub posiadania prawa do dziedziczenia gospodarstw, ochronie przed samowolą dziedzica i możliwości dochodzenia swoich praw na drodze sądowej, wprowadzeniu nowego modelu samorządu wiejskiego, oczynszowaniu chłopów oraz uwłaszczeniu. Przedstawił zmiany wprowadzone przez Sejm Wielki i Uniwersał połaniecki, zwracając przy tym uwagę, że te reformy z czasów powstania kościuszkowskiego nie zostały zrealizowane. Władze insurekcyjne nie miały wystarczających sił i środków, by wyszły one poza sferę postulatów. Autor przeszedł następnie do przedstawienia położenia chłopów w zaborze pruskim i austriackim. Skupił się zwłaszcza na reformach józefińskich, jak chociażby nadanie wolności osobistej chłopom w $1782 \mathrm{r}$. i próbie wprowadzenia oczynszowania w 1789 r. Mimo że ta reforma nie została zrealizowana, to miała kolosalne następstwa. Chłopi byli odtąd nieusuwalni z zajmowanych gruntów, mogli dochodzić swoich praw przed administracją państwową, także zmniejszeniu uległ wymiar pańszczyzny. Profesor Ślusarek wykazał, jak w praktyce wyglądała realizacja reform, posługując się inwentarzami gruntowymi z 1773 i 1789 r. z trzech wsi: Kosocic pod Krakowem, Koperni leżącej nieopodal Pińczowa i Łączyna w dobrach klasztoru Cystersów w Jędrzejowie. Na ich przykładzie dowiódł, że wprowadzanie zmian w położeniu chłopów wyglądało odmiennie w różnych regionach. Kończąc wystąpienie, zaproponował, aby inni badacze spróbowali przeprowadzić badania porównawcze na innych terenach.

Następnie prof. Cezary Kuklo z Uniwersytetu w Białymstoku wygłosił referat pt. „Wielkość i struktura chłopskiego gospodarstwa domowego w zachodniej części guberni grodzieńskiej w 1843 r.”. Głównymi problemami badawczymi poruszonymi w tym wystąpieniu było przedstawienie rozpoznanie dominującego w badanej społeczności modelu formowania się rodziny i gospodarstw domowych, a także ustalenie ich przeciętnej wielkości oraz określenie parametrów demograficznych powstawania rodziny. Zakres terytorialny referatu to parafia Trzcianne położona w łuku Biebrzy i Narwi między Tykocinem, Goniądzem i Knyszynem. Obejmowała ona wsie chłopskie, szlacheckie i mieszane. Profesor Kuklo jako źródła wykorzystał spis mieszkańców parafii, sporządzony przez jej proboszcza w 1743 r. Uzyskane dane zestawił w tabeli, dzieląc je pod względem płci ich „,kierownika” na kobiece i męskie. Zauważył przy tym, że dwie trzecie 
gospodarstw chłopskich stanowiły te oparte na rodzinie prostej, a gospodarstwa jednoosobowe, czyli prowadzone przez osoby samotne, występowały marginalnie. Nieznacznie większy odsetek stanowiły gospodarstwa „nierodzinne”, czyli prowadzone np. przez niezamężne rodzeństwo albo babkę z wnukiem. Profesor Kuklo zaprezentował, jak procentowo wyglądała sytuacja $\mathrm{w}$ gospodarstwach rozszerzonych, wskazując, że było ich o wiele mniej, gdy kierownikami były kobiety. Autor przedstawił również, jak wyglądała pokoleniowa struktura rodziny, a także jakiej wielkości były gospodarstwa w zależności od wieku kierownika. Kończąc, zaprezentował wyniki badań co do rodzaju zawieranych małżeństw i pochodzenia terytorialnego małżonków.

Norbert Tomaszewski, przedstawiciel Muzeum Rolnictwa im. ks. Krzysztofa Kluka w Ciechanowcu, w wystąpieniu ,„»W chłopy obrócone pospólstwo «'. Sytuacja poddanych Stefana hr. Ciecierskiego w latach 1850-1855", podjął temat z zakresu historii lokalnej, dotyczącej Ciechanowca i okolic oraz właściciela tychże dóbr, Stefana Ciecierskiego. W 1850 r. miejscowa ludność wystąpiła na drogę sądową, by uzyskać respektowanie ich przywilejów przez dziedzica miasta. Autor wskazał, że przyczyną sporu było to, że mieszkańcy Ciechanowca nazywali siebie mieszczanami, wykazując przy tym, że zajmują się handlem i rzemiosłem. Tymczasem Ciecierski twierdził, że są to chłopi i jako takich ich traktował, np. zmuszając ich do odrabiania pańszczyzny. Do rozpatrzenia sprawy oddelegowano śledczego, który poparł roszczenia Ciecierskiego i bezskutecznie usiłował przymusić miejscową ludność do podpisania dokumentu potwierdzającego ich przynależność do stanu chłopskiego. Autor przedstawił szczegółowo przebieg przeciągającego się sporu, łącznie z omówieniem zaboru mienia dokonanego przez dziedzica, który 284 skłócone ze sobą osoby pozostawił bez środków do życia. Wskazał również na kary cielesne i więzienia, które zostały wymierzone skarżącym się mieszkańcom Ciechanowca przez rozpatrujących sprawę urzędników carskich. Ostatecznie jednak pod wpływem ich skarg do miasta skierowano nową komisję, która ostatecznie orzekła o ich przynależności mieszczaństwa.

Doktor hab. Siarhiej Tokć z Białoruskiego Instytutu Prawoznawstwa wygłosił referat pt. „Czy pańszczyzna była przyczyną chłopskiej biedy? (na przykładzie Grodzieńszczyzny w I połowie XIX w.)”. W pierwszych słowach autor odniósł się do dotychczasowej historiografii białoruskiej, w której jednoznacznie negatywnie oceniano system folwarczno-pańszczyźniany. Według historyków białoruskich ostateczny kryzys tego systemu miał 
nastąpić w I połowie XIX w., doprowadzając do kryzysu demograficznego, wymierania społeczności wiejskich. Doktor hab. Tokć postanowił zweryfikować te tezy, opierając się na materiale źródłowym z kilku majątków ziemiańskich i państwowych ze wschodniej części powiatu grodzieńskiego. Z jego badań wynikało, że w omawianym okresie następował wzrost obciążeń pańszczyźnianych (nawet do sześciu dni odrobkowych w tygodniu) i zwiększenie się areału folwarków kosztem gruntów chłopskich. Według inwentarzy majątków z lat 40. XIX w. przeciętne dochody z gospodarstwa chłopskiego wynosiły od 90 do 120 rubli. Ich powinności w zależności od dóbr ziemskich wyceniano od 40 do 50 rubli, a podatki na rzecz państwa szacowano od 5 do 7 rubli. Autor zaznaczył jednocześnie, że chłopi na Grodzieńszczyźnie byli w zasadzie pozbawieni gotowizny, a transakcji w karczmach lub na targach, jarmarkach dokonywali, płacąc płodami rolnymi. Wysoki wymiar obciążeń na rzecz dworu w niektórych przypadkach doprowadzał do opuszczania gospodarstw przez chłopów. Natomiast gdy włościanie nie mieli pieniędzy na zapłacenie podatków, dziedzic danego majątku mógł im odebrać ziemię i włączyć ją do folwarku, a rodzinę chłopską zmienić w parobków. Niewiele lepiej wyglądała sytuacja poddanych w majątkach państwowych, poprawa nastąpiła po wprowadzeniu czynszu zamiast pańszczyzny w 1845 r. Mimo wyżej wymienionych czynników to nie one, ale klęski nieurodzaju w latach 50 . doprowadziły do wymierania miejscowej populacji. Doktor hab. Tokć dodawał jeszcze, że na podstawie porównania stanu zamożności chłopów w majątkach prywatnych i państwowych nie udało mu się znaleźć korelacji między odrabianiem pańszczyzny a biedą.

Doktor Henrihs Soms z Uniwersytetu w Daugavpils omówił temat „Historyk Bolesław Brażgo (1887-1957) o procesach agrarnych w Latgalii/ /Inflantach (do 1861 r.)", w którym zaprezentował badania i sylwetkę twórcy naukowych badań historycznych Inflant Polskich. Wystąpienie rozpoczął od nakreślenia rysu biograficznego tytułowego badacza edukacji, ukazania kariery zawodowej oraz dorobku naukowego. Następnie kolejno omówił trzy aspekty zawarte w pracach Brażnego: kategorie ludności chłopskiej w Łatgalii, ich poziom życia oraz projekty zniesienia pańszczyzny. Zaczął od przedstawienia różnych kategorii miejscowości występujących w XVII-wiecznych źródłach z omawianego terenu: miasteczko, słoboda, sioło, cmentarz, wioska, wieś, i skupił się na charakterystyce ostatniej z nich. Zaprezentował rodzaj zabudowy zagród chłopskich i strukturę rodzin włościańskich. Auror podzielił społeczność wiejską i określił jej udział pro- 
centowy w ogóle społeczności chłopskiej. Spośród nich najkorzystniejsze było położenie poddanych kościelnych i klasztornych, cieszących się najniższym wymiarem świadczeń. Doktor Soms omówił także wyniki badań Brażego na temat położenia włościan skarbowych i pańskich z podaniem dotyczących ich regulacji prawnych, zaczynając od 1797 r., a kończąc na zniesieniu pańszczyzny. Na zakończenie autor wystąpienia przytoczył kilka najważniejszych prac bohatera referatu.

Na zakończenie obrad prof. Norbert Kasparek z Uniwersytetu Warmińsko-Mazurskiego podjął temat zazwyczaj pomijany we współczesnej historiografii, a mianowicie „Kwestię chłopską w myśli politycznej Wielkiej Emigracji 1831-1861". Za ten stan rzeczy autor obwiniał ogólną tendencję do ucieczki od badań XIX w. na korzyść historii XX stulecia. W latach 50. ubiegłego wieku badania nad Wielką Emigracją były ukierunkowane na problemy światopoglądowe i socjalne. Niestety poddawano je ahistorycznemu wartościowaniu. Poza zainteresowaniami badaczy znalazła się myśl polityczna, która dopiero w ostatnim czasie stała się bardziej popularna. Przechodząc do meritum swojego wystąpienia, prof. Kasparek podjął kwestię radykalizacji polskiej myśli politycznej, począwszy od powstania listopadowego. Omówił stanowisko w kwestii chłopskiej Towarzystwa Demokratycznego Polskiego, ogłoszone w Małym i Wielkim Manifeście oraz licznych odezwach i artykułach prasowych. Autor przeszedł następnie do przedstawienia programu agrarnego stowarzyszeń związanych z Joachimem Lelewelem. Wspomniał również o najbardziej radykalnych żądaniach wysuwanych przez Gromady Ludu Polskiego, zawierających postulat wyzwoleńczej rewolucji dokonanej przez stan trzeci, w wyniku czego miał powstać naród o ludowym charakterze. Dla kontrastu prof. Kasparek nawiązał do stanowiska zajmowanego przez ks. Adama Czartoryskiego oraz Związku Jedności Narodowej i koncepcji uwłaszczeniowych za odszkodowaniem.

Wygłaszanym referatom towarzyszyły ożywione dyskusje, poruszające wiele interesujących wątków. Profesor Cezary Kuklo nawiązał do wystąpienia prof. Mikulskiego i podjętej przez niego negacji inicjującej roli szlachty w procesie zwiększenia pańszczyzny. Stanął on w obronie przyjmowanej do tej pory dominującej funkcji stanu uprzywilejowanego jako decyzyjnego w kwestiach gospodarczych i prawnym. Profesor Mikulski odpowiedział, że nie zaprzecza faktowi aktywizacji gospodarczej szlachty, ale przesunął ją na II połowę XVI w. Następnie głos zabrał dr Guzowski, zwracając uwagę na komercjalizację gospodarstw chłopskich w omawianym okresie, przy- 
chylając się do zdania o dynamicznym rozwoju folwarków we wskazanym przez jego przedmówcę przedziale czasowym. Stwierdził natomiast, że w I połowie XVI w. nie zaistniały warunki do ich rozwoju. Zwrócił również uwagę na rozwój folwarków w wielu krajach środkowoeuropejskich, gdzie nie było eksportu zboża na zewnątrz, a produkcja zaspokajała potrzeby rynku wewnętrznego. Doktor Guzowski wskazał na to, że takie potrzeby były również w naszym kraju, tym bardziej że występował wówczas wzrost demograficzny. Następnie odniósł się do podnoszonej w literaturze kwestii kryzysu monetarnego, który zanegował, stwierdzając, że produkcja mennicza w XVI-wiecznym państwie polsko-litewskim była na wysokim poziomie. Kończąc, powiedział, że eksport także był istotny, między 1510 a 1570 ro. wzrósł sześciokrotnie. Dwadzieścia pięć procent produkowanego w Polsce zboża trafiało na rynki zachodnioeuropejskie, co decydowało o krajowych cenach.

Innym wątkiem podjętym w dyskusji była przynależność stanowa ludności Podola. Doktor Guzowski zauważył, że problem podobny do poruszanego w referacie prof. Michałowskiego dotyczy pogranicza podlasko-mazowieckiego, gdzie istnieją wsie, a nawet parafie, w których nie było chłopów. Jeśli chodzi o określenie przynależności stanowej miejscowej ludności, to wskazywał on na potrzebę przebadania tego problemu na podstawie rejestrów podatkowych lub metody progresywnej, przy użyciu XVII- i XVIII-wiecznych spisów podatkowych. Profesor Michałowski zwrócił uwagę, że jeśli chodzi o Podole, to miało ono swoją specyfikę z uwagi na zagrożenie tatarskie i bunty kozackie wpływające na niewielki odsetek ludności chłopskiej. Odnosząc się do metody badawczej zaproponowanej przez dr Guzowskiego, stwierdził, że nie da się jej zastosować w przypadku badanego przez niego regionu, gdyż Turcy w końcu XVII w. zmienili strukturę ludnościową na tym obszarze. Dodatkowo wiele archiwaliów przechowywanych w archiwum w Kamieńcu Podolskim spłonęło w $2003 \mathrm{r}$.

Podczas dalszej dyskusji zastanawiano się, jak zdefiniować chłopów i mieszczan, gdyż wielu mieszkańców miast pochodziło ze wsi. A co za tym idzie - możliwe jest, że bliskie prywatne relacje między stanami opierają się głównie na więzach rodzinnych. Jeśli natomiast chodzi o zakup ziemi mieszczańskiej przez chłopów, zazwyczaj nie wchodziły w grę parcele miejskie, ale łany, przez co rodzaj wykonywanej pracy i status społeczny nabywcy w zasadzie się nie zmieniał. Dyskusji poddano również wątek wybierania rodziców chrzestnych dla dzieci chłopskich spośród mieszczan. 
Zastanawiano się, w jakim stopniu rodzice celowo dokonywali takiej decyzji, a w jakim chodziło o jak najszybszy wybór chrzestnych w przypadku, gdy świątynia znajdowała się w mieście.

Dużo uwagi poświęcono projektowi modelu serfdom. Zgodnie podkreślano, że kwantytatywne badania porównawcze są jak najbardziej potrzebne, jednak pojawiła się wątpliwość co do wyrażonych liczbowo wyników. Profesor Mikulski obawiał się, czy przy ich analizie nie dojdzie do przekłamań, i postulował, by próbować opisywać oraz porównywać poszczególne aspekty serfdom, a nie wyrażać je w systemie zerojedynkowym. Podobnie prof. Kuklo zgłaszał obawy, że porównywanie zależności chłopskich w wielu dobrach może doprowadzić do uzyskania średniej nieoddającej rzeczywistego obrazu sytuacji.

Odmiennego zdania był prof. Wiślicz, dostrzegający w modelu kwantytatywnym duży potencjał. Stwierdził, że współczynnik serfdom nie ma oceniać zjawisk, ale wskazywać na różne możliwości wolności gospodarczej. Zaproponował także, by wziąć pod uwagę inne współczynniki, np. czy model rodziny był warunkowany przez wolność jednostki? jak wyglądały możliwości awansu społecznego? Doktor Poniat zaznaczył, że projekt jest dopiero na etapie dyskusji i może okazać się, że wiele zmiennych jest niemierzalnych albo są możliwe do zmierzenia tylko w jednym miejscu, a w innym już nie. Końcowe wyniki zamieszczone w indeksie nie będą czystym opisem, ale wskaźnikiem sugerującym występowanie lub brak danego zjawiska. Uzyskane wyniki zostaną poddane wartościowaniu ze względu na ich wpływ na serfdom. Doktor Poniat odniósł się także do pomysłu umieszczenia w swoim projekcie czynnika rodziny, ponieważ po jego wprowadzeniu nie da się sprawdzić, czy koreluje on z serfdom. Doktor Guzowski bronił liczbowego wyrażenia badanego problemu, gdyż jest ono dominujące we współczesnych badaniach nad gospodarką czy potencjałem ludzkim. Zwracał także uwagę na fakt, że w historiografii zachodnioeuropejskiej serfdom na wschód od Łaby jest jednolity, nie podlega zróżnicowaniu ze względu na regiony. W związku z tym przed badaczami ze środkowej i wschodniej części naszego kontynentu stoi zadanie wykazania owych regionalnych różnic.

Konferencja „Chłopi na ziemiach dawnej Rzeczypospolitej do czasów uwłaszczenia" okazała się bardzo owocna. Zarówno referaty, jak i następująca po ich wygłoszeniu dyskusja dotykały wielu ciekawych wątków, rzadko poruszanych we współczesnych badaniach historycznych. Ważną propozycją badawczą, mogącą znacznie wzbogacić dotychczasowy stan 
wiedzy o chłopach w epoce nowożytnej, jest projekt poświęcony określenia współczynnika serfdom dla przedrozbiorowej Rzeczypospolitej. Ponowne przyjrzenie się dorobkowi polskiej historiografii marksistowskiej może wpłynąć na kształt współczesnych badań nad społecznością wiejską. Wszystkie wygłoszone w czasie dwóch dni referaty zostaną opublikowane w tomie pokonferencyjnym zredagowanym przez prof. Dorotę Michaluk. 